\title{
Description of a Neotropical New Species of Oxysarcodexia Townsend, 1917 (Diptera: Sarcophagidae)
}

\author{
Carina Mara de Souza \& Maria Lígia Paseto
}

Universidade Estadual de Campinas, e-mail: carina mara@yahoo.com.br (Autor para correspondência ${ }^{\bowtie}$ ), ligiapaseto@gmail.com.

\section{EntomoBrasilis 8 (3): 222-225 (2015)}

Registered in ZooBank: urn:lsid:zoobank.org:pub:CDE87122-53B3-4Ao9-B228-A4DCD87BDE3C

Nomenclatural Acts: urn:lsid:zoobank.org:act:0851654B-8EFB-4471-9EOA-EEOOAFADBO6O

Abstract. A new species of Oxysarcodexia Townsend, 1917 (Diptera: Sarcophagidae) from Brazil is described based on male specimens. This is a mainly Neotropical genus of flesh flies, with few species also present in Nearctic, Australasian and Oceanian Regions. Its species have been associated with decomposing organic matter (feces of mammals or birds - dung-breeders species) and have potential forensic importance when associated with carcasses (attracted fauna and, in some cases, true carrion-breeding species). Digital photographs of the habitus in lateral view and of the terminalia in lateral, posterior and ventral views are provided. Oxysarcodexia mineirensis sp. n. is close-related to "Xarcophaga species-group" (i.e. with a postero-distal phallic enlargement) and is similar to Oxysarcodexia favorabilis (Lopes, 1935) due to the conformation of the terminalia, especially the phallus flower-like shaped.

Keywords: Brazil, Flesh fly; Morphology; Oxysarcodexia mineirensis sp. n.; Taxonomy

\section{Descrição de Uma Nova Espécie Neotropical de Oxysarcodexia Townsend, 1917 (Diptera: Sarcophagidae)}

Resumo. Uma nova espécie de Oxysarcodexia Townsend, 1917 (Diptera: Sarcophagidae) é descrita com base em espécimes machos. As espécies deste gênero de sarcofagídeos apresentam distribuição majoritariamente Neotropical, com algumas espécies ocorrendo também nas regiões Neártica, Australásia e Oceânica. As espécies deste gênero podem ser encontradas associadas à matéria orgânica em decomposição (fezes de mamíferos ou aves - espécies coprófilas) e podem apresentar importância forense quando associadas a carcaças (fauna atraída e, em alguns casos, espécies que se criam). Fotografias digitais do hábito em vista lateral e da terminália em vistas lateral, posterior e ventral são apresentadas. Oxysarcodexia mineirensis sp. n. pertence ao "grupo Xarcophaga" (i.e. possui o falo alargado postero-distalmente) e contém similaridades com Oxysarcodexia favorabilis (Lopes, 1935) devido à conformação da terminália, especialmente o formato do falo, semelhante a uma flor.

Palavras-chave: Brasil, Morfologia; Oxysarcodexia mineirensis sp. n.; Sarcofagídeo; Taxonomia.

$(0$ xysarcodexia Townsend, 1917 (Diptera: Sarcophagidae) comprises 83 species (Pape 1996; Soares \& MelloPATIU 2010) with mainly Neotropical distribution, but few species also expanding their occurrence to the Nearctic, Australasian and Oceanian regions (LoPES 1973; LoPES \& Tibana 1987; PAPE 1996). This genus is considered monophyletic based on the autapomorphic character: presence of a lateral triangular extension of the phallic tube ("tooth-like") above the vesica (Giroux et al. 2010). Species within Oxysarcodexia genus are recognized by the presence of postalar wall setose; mid femur of the males with ctenidium of flattened spines; darkish tegula and lighter basicosta (commonly light brown); male sternite 5 (ST5) deeply cleft with almost parallel branches (few exceptions of V-shaped branches); phallus unsegmented, with three conducting styli and a "tooth-like" extension of the phallic tube above the vesica; and vesica elongated, conspicuous, and always well developed (Lopes 1946; Dodge 1966; Pape 1996; Carvalho \& Mello-Patiu 2008; Silva \& Mello-Patiu 2008).

Species of Oxysarcodexia are important from the ecological standpoint by acting as decomposers of organic material, as feces of mammals or birds (dung-breeders) and carcasses (some species are true carrion-breeders, but the great majority composes the attracted fauna) (PAPE \& DAHLEM 2010; CARVALHO et al. 2012). Thus, these flesh flies are very frequent in forensic and faunistic studies performed in the Neotropical region, especially in South America (e.g. LinHares 1981; D'Almeida 1984; Dias et al. 1984; Oliveira-Costa et al. 2001; Barros et al. 2008; Rosa et al. 2011; Mello-Patiu et al. 2014).

Xarcophaga was proposed as a monotypic genus by DODGE (1968), with the description of Xarcophaga xon Dodge, 1968, which was considered different of Oxysarcodexia due to the presence of an elongated and slender phallus, with an apical distiphallic enlargement. After that, Lopes (1975) re-examined some species, re-described O. pallisteri Dodge, 1966 and synonymized X. xon with Oxysarcodexia, considering these species morphologically close to Oxysarcodexia favorabilis (Lopes, 1935) and Oxysarcodexia vittata (Walker, 1836). He also recommended an analysis of the females of these species in order to confirm the existence of these two separated genera. This relationship between Xarcophaga and Oxysarcodexia was also pointed out by SOARES \& Mello-Patiu (2010). Oxysarcodexia, Xarcophaga, Apelophyla Hall and Hybopygia Enderlein were considered distinct valid genera by LOPES (1982). Posteriorly, they were united within Oxysarcodexia by PAPE (1996). On the moment, the "Xarcophaga species-group", i.e., the species with a characteristic enlarged apex of the distiphallus, here considered as a distal enlargement

Funding Agency: CNPq 
- of the juxta, includes Oxysarcodexia favorabilis (Lopes, 1935), Oxysarcodexia fraterna Lopes, 1946, Oxysarcodexia nitida Soares \& Mello-Patiu, 2010, Oxysarcodexia notata Soares \& Mello-Patiu, 2010, Oxysarcodexia pallisteri Dodge, 1966, Oxysarcodexia peruviana (Lopes, 1973), Oxysarcodexia vittata (Walker, 1836) and Oxysarcodexia xon (Dodge, 1968) (Lopes 1975; Soares \& Mello-Patiu 2010).

A new species of Oxysarcodexia from Minas Gerais, Brazil is described and illustrated. Its male terminalia resembles that presented by the species considered belonging to the "Xarcophaga species-group".

\section{MATERIAL AND METHODS}

Five male specimens were examined under a stereomicroscope Carl Zeiss Stemi SV11 ${ }^{\mathrm{TM}}$. These males were pinned and the terminalia was pulled out with the aid of an entomological probe and minuten and/or fine entomological pins were set to avoid the retraction of the terminalia until the specimens dry (PAPE \& DAhlEM 2010). Terminology follows McAlpine (1981) for external characters and Mello-Patiu \& Pape (2000) and Giroux et al. (2010) for male terminalia. Measurement of the body length was obtained by including the length of the head (without considering the antennae), thorax (from the neck to the posterior margin of the scutellum) and abdomen (from the anterior margin of abdominal tergite 2 to the posterior margin of tergite 5 plus terminalia length), in order to offset bias caused by any eventual curvature of the specimens.

Digital photographs were taken of the lateral habitus and of the male terminalia in lateral, anterior, and posterior views using a digital camera Carl Zeiss AXIOCAM MRc ${ }^{\mathrm{TM}}$ (5 megapixels), mounted on a Carl Zeiss STEREO DISCOVERY.V12 ${ }^{\mathrm{TM}}$ stereoscope. The images were posteriorly processed, whenever needed, using Adobe $^{\circledR}$ Lightroom ${ }^{\circledR}$ and/or Photoshop ${ }^{\circledR}$ software. For each view, photographs were taken with extended depth-focus and were stacked using Zerene Stacker ${ }^{\mathrm{TM}}$ software. Label information of the new species was transcribed without any modification; a forward slash (/) was used to separate individual labels and any additional comments about the label data were given in square brackets.

Type specimens are deposited pinned in the collections of the Museu Nacional (MNRJ), Universidade Federal do Rio de Janeiro, Rio de Janeiro, Brazil, and Museu de Zoologia da Universidade Estadual de Campinas "Adão José Cardoso" (ZUEC), Universidade Estadual de Campinas, Campinas, São Paulo, Brazil, as posteriorly stated for each specimen.

\section{RESULTS}

\section{Oxysarcodexia mineirensis sp. $\mathbf{n}$.}

\section{urn:lsid:zoobank.org:act:0851654B-8EFB-4471-9EoA- EEOOAFADBo60}

Type material. Male holotype: BRAZIL: Minas Gerais, Uberlândia, Fazenda Experimental do Glória. Mata (P2). 26 julho 2012. M.L. Paseto \& L.S. Faria / Oxysarcodexia sp. n. / Holotype (MNRJ). Paratypes: BRAZIL: Minas Gerais, Uberlândia, Fazenda Experimental do Glória. Mata (P2). o8 março 2013. M.L. Paseto \& L.S. Faria / Oxysarcodexia sp. n. / Paratype [1 male] (MNRJ). BRAZIL: Minas Gerais, Uberlândia, Fazenda Experimental do Glória. Mata. 25-VII-2012. M.L. Paseto \& L.S. Faria / Oxysarcodexia sp. n. / Paratype [1 male] (MNRJ). BRAZIL: Minas Gerais, Uberlândia, Fazenda Experimental do Glória. M.L. Paseto \& L.S. Faria [date of collection not available] / Oxysarcodexia sp. n. / Paratype [1 male] (ZUEC). BRAZIL: ส Minas Gerais, Uberlândia, Fazenda Experimental do Glória M.L. Paseto \& L.S. Faria [date of collection not available] / Oxysarcodexia sp. n. / Paratype [1 male] (ZUEC).
Description. Male (Figure 1-a). Total length $=6.8-8.4 \mathrm{~mm}$ $(\mathrm{n}=5)$.

Head. Fronto-orbital, parafacial and postocular plates with golden microtomentum. Occiput blackish with pale golden microtomentum. First two rows of occipital setae black, others yellowish. Front ranging about 0.10-0.11x head width at level of ocellar triangle. Frontal vitta brownish, with a row of 9-10 frontal setae. Inner vertical seta ranging from 3.0 to $4.7 \mathrm{x}$ as long as the postoculars. Outer vertical seta about $1.2-1.8 \mathrm{x}$ as long as the postoculars. Ocellar setae as long as the uppermost frontal seta. One reclinate orbital seta about 1.1-1.4x longer than the longest frontal setae. Proclinate orbital setae absent. Gena and postgena with golden microtomentum and black setae. Face with golden microtomentum. Pedicel dark brown. First flagellomere with pale golden microtomentum, about $1.7-2.7 \mathrm{x}$ as long as pedicel. Arista dark brown and long plumose on basal $2 / 3$. Palpus dark brown. Vibrissa dark brown, well-developed, and about 1.4x as long as the arista. Proboscis well-developed, dark brown, and with golden setulae apically.

Thorax. Golden microtomentum with three black stripes. Brownish thoracic spiracles. Greater ampulla oval. Chaetotaxy: acrostichals $=0+1$, dorsocentrals $=3+3$, intra-alars $=2+2$, supra-alars $=2+3$, postalars $=2$, postpronotals $=3$ (first one smaller than the others), notopleurals 4 (2 long primaries and 2 shorter subprimaries), katepisternals $=3$ (middle one inserted slightly below the others), meropleurals $=8$, postalar wall with black setulae, scutellum with no apical setae, one basal, one subapical and one discal seta. Prosternum with few scattered setulae on the distal half.

Wings. Hyaline, about $0.8 \mathrm{x}$ the mean body size, tegula and wing veins dark brown, basicosta whitish yellow, stem vein bare dorsal and ventrally, $\mathrm{R}_{1}$ bare, $\mathrm{R}_{4+5}$ with setulae in proximal $3 / 4$ of distance to $\mathrm{r}-\mathrm{m}$, costal spine-seta short, third costal sector with few ventral setae, upper and lower calypteres white with short white setulae dorsally.

Legs. Dark brownish. Fore femur with one posterodorsal, one posterior and one posteroventral row of setae. Fore tibia with two anterodorsal setae and one posterior, one posterodorsal and one posteroventral seta. Mid femur with two rows of ventral long setae, one row of anterodorsal setae, 2 pre-apical posterodorsal setae, ctenidium with flattened spines. Mid tibia with two anterior setae, one posterodorsal seta, two posterior, one dorsal preapical seta, and one long apical ventral seta. Hind femur with a row of long posterodorsal setae and a row of short posteroventral setae, one apical anteroventral row of setae and one long posteroventral seta. Hind tibia with two anteroventral setae, three anterodorsal setae, one dorsal preapical seta, and one posterodorsal seta. Tarsomeres of fore, mid and hind legs dark brownish.

Abdomen. Black with golden microtomentum. Tergites 2-5 with dorsal and lateral golden spots. Tergites 2-3 with one lateral marginal seta. Tergite 4 with 2-3 lateral marginal and one medial marginal seta. Tergite 5 with 13 strong setae along the posterior margin. Sternites $2-4$ brownish, with setae along the edges and a few shorter scattered setae. Sternite 5 with posterior margin with a deep cleft of parallel edges.

Terminalia (Figure 1-b, -c, -d, -e). Syntergosternite $7+8$ yellowish with golden microtomentum, scattered short black setae, and 6 marginal setae. Epandrium yellowish with golden microtomentum and black setae. Posterior margin of cerci slightly sinuous in lateral view, darker in the distal $1 / 4$, with pointed apex and long black setae on the basal half. Inner margins of the cerci in posterior view almost parallel. Cerci and surstyli cover with very small yellowish setulae. Surstylus triangular, with a few marginal black short setae. Postgonite slender and slightly curved on the apical portion, with rounded apex. Pregonite elongated, as long as half of the phallic length, broader and lighter than the 
postgonite, almost straight with rounded apex ("spoon-like" shape). Phallus well-sclerotized slightly curved on the posterior margin. Phallic tube with a ventrolateral band more sclerotized. Phallic tube antero-proximally with a lateral triangular extension ("tooth-like") above the vesica. Distiphallus trumpet-shaped, with distal membranous appearance. Juxta with membranous projections with folded margins. Lateral and median styli apically positioned; median stylus long and narrow and lateral stylus short and broad. Vesica well developed, sclerotized and dark brown. Vesical proximal section as a lever-shaped arm, proximally linked to the medio-proximal area of the phallic tube. Vesical distal section slender oblong-shaped with distal serrated edge.

\section{Female. Unknown.}

Distribution. NEOTROPICAL - Brazil (Minas Gerais).
Etymology. The specific epithet is a noun in apposition and refers to the type locality.

Remarks. These specimens were collected associated to pig carcasses in a region of a semi-deciduous forest located in a Cerrado (savannah-like) area, belonging to the Fazenda Experimental do Glória, one of the facilities of the Universidade Federal de Uberlândia, Minas Gerais, Brazil.

Oxysarcodexia mineirensis $\mathbf{s p .} \mathbf{n}$. is very similar to $O$. favorabilis due to the conformation of the terminalia, especially the phallus flower-like shaped and the distal enlargement of the juxta, very remarkable in the "Xarcophaga species-group". Thus, we suggest the inclusion of $O$. mineirensis $\mathbf{s p .} \mathbf{n}$. in this species-group along with O.favorabilis, O. fraterna, O. nitida, O. notata, O. pallisteri, O. peruviana, O. vittata, and O.xon.
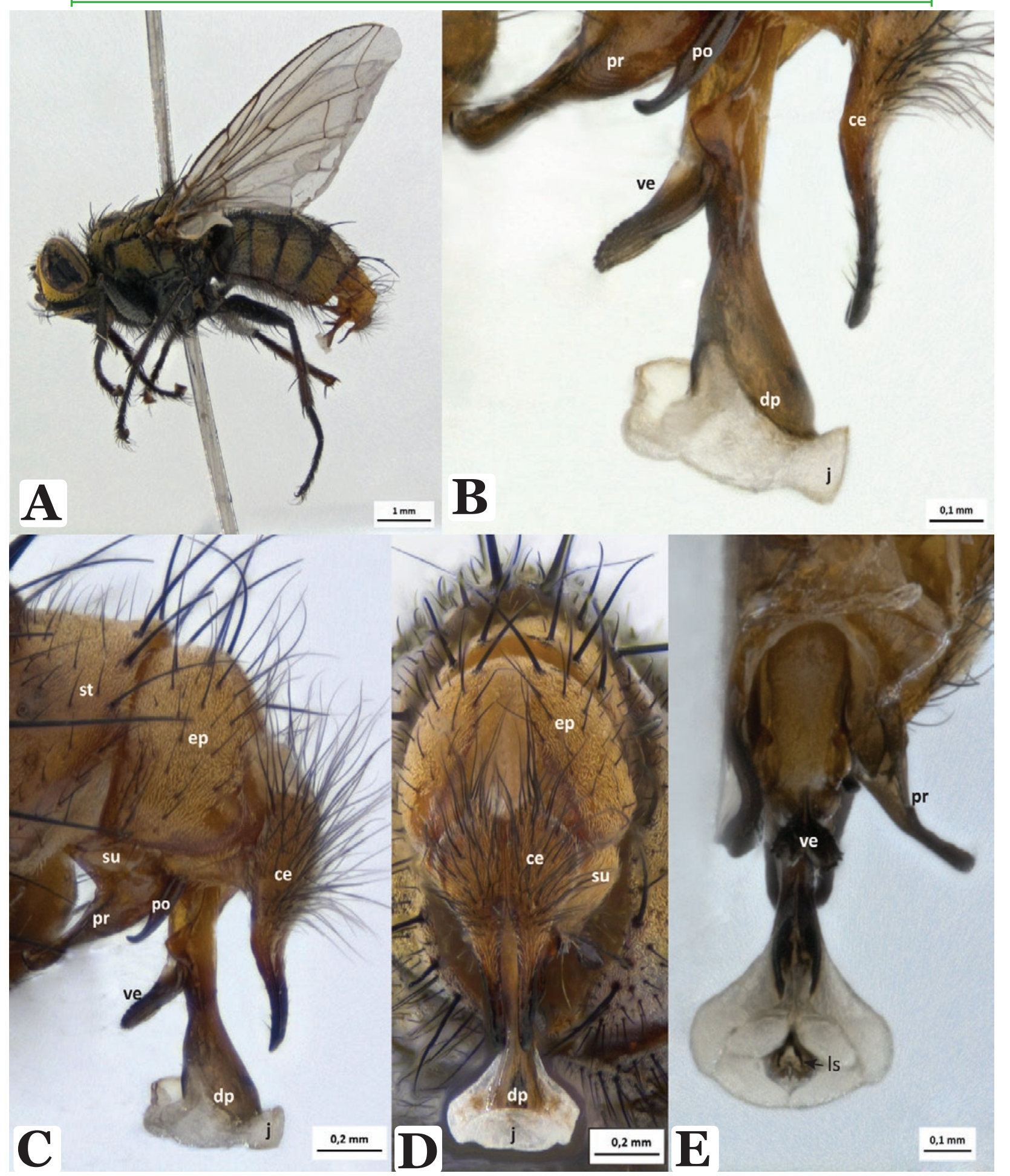

Figure 1. Oxysarcodexia mineirensis sp. n., male holotype. a. habitus, lateral view, b. terminalia, lateral view, phallus in detail, c. terminalia, lateral

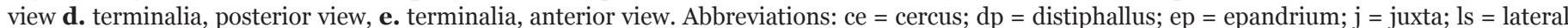
stylus; po = postgonite; $\mathrm{pr}=$ pregonite; st = syntergosternite $7+8$; su = surtylus; ve = vesica. 


\section{ACKNOWLEDGEMENTS}

We would like to thank Conselho Nacional de Desenvolvimento Científico e Tecnológico (CNPq) for the scholarship support to the second author; the University of Campinas for providing facilities, workspace and equipment; Lucas Silva de Faria for helping in the collection of the specimens; Júlio Mendes for providing means for the accomplishment of the collection; Cátia Antunes de Mello Patiu for early discussion about this new species; Patricia Jacqueline Thyssen, Marcela Aquiyama Alonso, and Marina Ferrari Klemm de Aquino for their comments about this manuscript.

\section{REFERENCES}

Barros, R.M., C.A. Mello-Patiu \& J.R. Pujol-Luz, 2008. Sarcophagidae (Insecta, Diptera) associados à decomposição de carcaças de Sus scrofa Linnaeus (Suidae) em área de Cerrado do Distrito Federal, Brasil. Revista Brasileira de Entomologia, 52: 606-609.

Carvalho, C.J.B. \& C.A. Mello-Patiu, 2008. Key to the adults of the most common forensic species of Diptera in South America. Revista Brasileira de Entomologia, 52: 390-406.

Carvalho, C.J.B., J.A. Rafael, M.S. Couri \& V.C. Silva, 2012. "DIPTERA", p. 701-743. In: Rafael, J.A., G.A.R. Melo, C.J.B. Carvalho, S. Casari \& C. Constantino (Eds.). Insetos do Brasil: diversidade e taxonomia. Holos Editora, Ribeirão Preto, São Paulo, Brasil, 810 p.

D’Almeida, J.M., 1984. Sinantropia de Sarcophagidae (Diptera) na região metropolitana do Estado do Rio de Janeiro. Arquivos da Universidade Federal Rural do Rio Janeiro, 7: 101-110.

Dias, E.S., D.P. Neves \& H.S. Lopes, 1984. Estudos sobre a fauna de Sarcophagidae (Diptera) de Belo Horizonte - Minas Gerais I - Levantamento taxonômico e sinantrópico. Memórias do Instituto Oswaldo Cruz, 79: 83-91.

Dodge, H.R., 1966. Some new or little-known Neotropical Sarcophagidae (Diptera), with a review of the genus Oxysarcodexia. Annals of the Entomological Society of America, 59: 674-701.

Dodge, H.R., 1968. The Sarcophagidae of Barro Colorado Island, Panama (Diptera). Annals of the Entomological Society of America, 61: 421-450.

Giroux, M., T. Pape \& T.A. Wheeler, 2010. Towards a phylogeny of the flesh flies (Diptera: Sarcophagidae): morphology and phylogenetic implications of the acrophallus in the subfamily Sarcophaginae. Zoological Journal of the Linnean Society, 158: $740-778$.

Linhares, A.X., 1981. Synanthropy of Calliphoridae and Sarcophagidae (Diptera) in the city of Campinas, São Paulo, Brazil. Revista Brasileira de Entomologia, 25: 189-215.

Lopes, H.S. \& R. Tibana, 1987. On Oxysarcodexia (Diptera, Sarcophagidae), with descriptions of five new species, key, list and geographic distribution of the species. Revista Brasileira de Biologia, 47: 329-347.

Lopes, H.S., 1946. Contribuição ao conhecimento das espécies do gênero Oxysarcodexia Townsend, 1917 (Diptera,

\section{Suggestion citation:}

Souza, C.M. de \& M.L. Paseto, 2015. Description of a Neotropical New Species of Oxysarcodexia Townsend, 1917 (Diptera: Sarcophagidae). EntomoBrasilis, 8 (3): 222-225.

Available in: $\underline{\text { doi:10.12741/ebrasilis.v8i3.524 }}$
Sarcophagidae). Boletim da Escola Nacional de Veterinária, 1: 62-134.

Lopes, H.S., 1973. Collecting and rearing sarcophagid flies (Diptera) in Brazil, during 40 years. Anais da Academia Brasileira de Ciências, 45: 279-291.

Lopes, H.S., 1975. New or little known Oxysarcodexia (Diptera, Sarcophagidae). Revista Brasileira de Entomologia, 35: 461483.

Lopes, H.S., 1982. The importance of the mandible and clypeal arch of the first instar larvae in the classification of the Sarcophagidae (Diptera). Revista Brasileira de Entomologia, 26: 293-326.

McAlpine, J.F., 1981. "MORPHOLOGY AND TERMINOLOGY ADULTS”, p. 9-63. In: McAlpine, J.F., B.V. Peterson, G.E. Shewel, H.J. Teskey, J.R. Vockeroth \& D.M. Wood (Eds.). Manual of Nearctic Diptera. Vol. 2. Ottawa. Research Branch, Agriculture Canada, Monograph 28, 457 p.

Mello-Patiu, C.A.\&T. Pape, 2000. Definitions of Dexosarcophaga Townsend, 1917 and Sarcofartiopsis Hall, 1933, including two new species and a redescription of Sarcofartiopsis cuneata (Townsend, 1935) (Diptera, Sarcophagidae). Boletín de Entomología Venezolana, 15: 181-194.

Mello-Patiu, C.A., M.L. Paseto, L.S. Faria, J. Mendes \& A.X. Linhares, 2014. Sarchophagid [sic!] flies (Insecta, Diptera) from pig carcasses in Minas Gerais, Brazil, with nine new records from the Cerrado, a threatened Neotropical biome. Revista Brasileira de Entomologia, 58: 142-146.

Oliveira-Costa, J., C.A. Mello-Patiu \& S.M. Lopes, 2001. Dípteros muscóides associados com cadáveres humanos na cena da morte no estado do Rio de Janeiro - Brasil. Boletins do Museu Nacional de Zoologia, 464: 1-6.

Pape, T. \& G.A. Dahlem, 2010. "SARCOPHAGIDAE", p. 13131335. In: Brown, B.V., A. Borkent, J.M. Cumming, D.M. Wood, N.E. Woodley \& M. Zumbado (Eds.). A Manual of Central American Diptera. Vol. 2. NRC Research Press, Ottawa, 728 p.

Pape, T., 1996. Catalogue of the Sarcophagidae of the world (Insecta: Diptera). Memoirs on Entomology International, 8: 1-558.

Rosa, T.A., M.L.Y. Babata, C.M. Souza, D. Sousa, C.A. MelloPatiu, F.Z. Vaz-de-Mello \& J. Mendes, 2011. Arthropods associated with pig carrion in two vegetation profiles of Cerrado in the State of Minas Gerais, Brazil. Revista Brasileira de Entomologia, 55: 424-434.

Silva, K.P. \& C.A. Mello-Patiu, 2008. Morfologia comparada da terminalia masculina de quatro espécies de Oxysarcodexia Townsend, 1917 (Diptera, Sarcophagidae). Arquivos do Museu Nacional do Rio de Janeiro, 66: 363-372.

Soares, W.F. \& C.A. Mello-Patiu, 2010. Two new Neotropical species of the genus Oxysarcodexia Townsend (Diptera, Sarcophagidae). Revista Brasileira de Entomologia, 54: 7275 .

\section{Received in: 04/16/2015}

Accept in: 07/17/2015
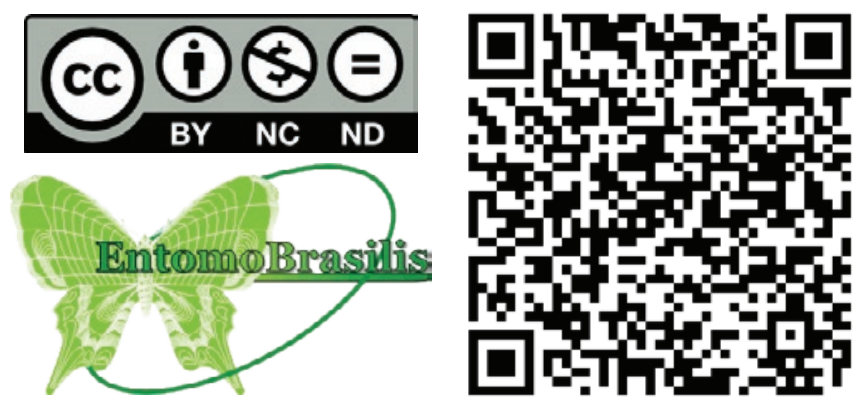